\title{
NENETSIEN LAULUJEN MUSIIKILLISET RAKENTEET $^{1}$
}

\section{Nenetsit}

Nenetsit (aiemmin: jurakkisamojedit) lukeutuvat inuitien, tšuktšien ja saamelaisten ohella merkittävimpiin arktisiin alkuperäiskansoihin kielen ja kulttuurin säilymisen ennusteiden suhteen. Noin 34.000:sta nenetsistä ainakin $80 \%$ puhuu omaa kieltään äidinkielenään ja suuri osa harjoittaa edelleen paikallisia perinteisiä elinkeinomuotoja, poronhoitoa ja riistan pyyntiä. Nenetsien asuinseudut ulottuvat laajalle alueelle Pohjoisen Euraasian, Obin ja Jenisein pohjoisilla tundrilla.

Obin ja Jenisein välissä sijaitsevan Pur-joen vesistöalueen taigalla asuu erillinen metsänenetseiksi kutsuttu pienehkö ryhmä. Metsänenetsit eroavat tundranenetseistä kielellisesti enemmän kuin suomalaiset virolaisista. Myös metsänenetsien keskuudessa oman kielen puhujien suhteellinen osuus on suuri.

Nenetsi ja muut samojedikielet ovat suomalais-ugrilaisten kielten kaukaisia sukulaisia. Yhteisestä kantauralilaisesta ajasta on n. 6000-7000 vuotta, joten sukulaisuus rajoittuu vain joihinkin kielen elementteihin, esim. subarktisten myöhäispaleoliittisten ja varhaisrautakautisten pyyntikulttuurien sanastoon (xalja 'kala'; séw" 'silmä'; pja 'puu', ym.)

1) Tämä artikkeli on tiivistetty ja uudistettu versio pro gradu -tutkielmani (Niemi 1989) luvusta "Nenetsien laulujen musiikilliset rakenteet". 


\section{Siperian kansojen musiikin tutkimus}

Siperian kansojen musiikin - ja tässä tapauksessa erityisesti sävelrakenteiden - tutkimus on käytännön syistä suurimmaksi osaksi neuvostoliittolaisten tutkijoiden tekemää. Neuvostotutkijat, jotka useimmiten ovat olleet joko musiikkitieteilijöitä tai folkloristeja, ovat tehneet Siperiassa paljon kenttätyötä ja keränneet arvokasta materiaalia Siperian eri kansojen musiikista. Heidän toimintaansa ohjailevana yleisenä teoreettisena viitekehyksenä tai metateoriana on suhteellisen usein ollut kulttuurievolutionistinen ajattelu, joka kenties haitallisimmillaan on saanut selkeän normatiivisia piirteitä: ulkoeurooppalaisen musiikin kehityskaaren ääripiste on eurooppalaisiin muotoihin ja merkityksiin siirtynyt, vaikkakin kansallisia erityispiirteitä kantava musiikki. Esimerkiksi 1960-luvulla jakuuttilaisesta kansanlaulusta monografian laatinut S. A. Kondratjev toteaa jakuuttilaisista lauluista: "Luonnollisesti lukijalla saattaa herätä kysymys: 'Kuinka sitten sisällyttää useat tämänkaltaiset sävelmät, vaikka niiden harmonisoituina sovituksinakin, kansainvälisen musiikin yleisiin normeihin ja sen tasavireiseen järjestelmään?' Tehtävä on helppo. Tarvitsee vain pitäytyä käyttämästä sellaisia ylimääräisiä ääniä puolisävelaskelissa, jotka eivät olemukseltaan millään tavoin kuvasta sävelasteikkoa."2 Tämä ei luonnollisestikaan kuvaa 1990-luvun tilannetta Siperian kansojen musiikin tutkimuksen suhteen. Uutta musiikkiperinteiden tutkimuksen ilmastoa edustavat venäläiset $(\mathrm{mm}$. I. A. Bogdanov ja T. D. Bulgakova) virolaiset (Miik Sarv, Triinu Ojamaa) ja alkuperäiskansoja itseään edustavat musiikin ja kulttuurin tutkijat (A. G. Gomon, E. A. Aleksejev, J. T. Pußkarjova, L. Taragupta).

\section{Nenetsien laulut}

Nenetsiläisten laulujen voidaan neuvostoliittolaisten folkloristien ja musiikkitieteilijöiden tavoin sanoa kuuluvan "varhaisen" tai "arkaaisen" melodianmuodostuksen sävelmaailmaan. Tämä käsitys pohjautuu laulujen tonaalisten perusrakenteiden tarkasteluun: nenetsiläisten perinteisten laulujen melodiarunko koostuu muutamasta sävelestä, jotka puolestaan muodostavat sävelmän toistuvan melodiasäerakenteen. Sävelten intervallisuhteille luonteenomainen piirre on anhemitonisuus eli puolisävelaske-

2) Kondratjev 1963, 26; sitaatti Aleksejev 1976, 5) 4-55. 
lettomuus ${ }^{3}$, kuten yleensäkin arktisten tai subarktisten varhaiskantaisten musiikkikulttuurien tonaalisissa perusjärjestelmissä.

Gomon viittaa toisaalta nenetsiläisestä laulusta puhuessaan puheintonaation varhaismuotoihin, otaksuessaan esimerkiksi arktisen laulun edustavan vaihetta ennen puheintonaatiota. Kehittynyttä puhetta edeltäväksi otaksuttu kommunikatiivisen intonaation vaihe antaa myös vihjeen selittää melodisen intonaation ilmeistä etuasemaa nenetsien vokaalimuotojen alkuperässä. Se tosiasia, että intonointimekanismi kehittyi paljon artikulointielimiä aiemmin täytyy liittää musiikin yleistä alkuperää koskevaan hypoteesiin. Nenetsien musiikin ollessa kyseessä on tärkeää tietää, että sellainen ilmiö kuin laulaminen ilman tekstiä, kaksiäänisenä soolona on säilynyt vain samojedien muinaisilla kotiseuduilla, eri puolilla Etelä-Siperiaa. On lisäksi todistettu, että kaksiäänisen soolon laulamisen aikana tarvittava mekanismi vastaa sellaista, joka on ominainen puhetta edeltävän inhimillisen kommunikaation akustiselle ja fysiologiselle muodolle. Tämän perusteella voidaan otaksua musiikillisen ajattelun kehittyneen ennen kehittynyttä puhetta. Hypoteesi on sopusoinnussa nenetsien laulumuotojen analyysista saatujen tulosten ja niihin liittyvien musiikillisen rytmiikan ensisijaisuutta ja kypsyyttä koskevien johtopäätösten kanssa. ${ }^{4}$

Taimyrin nganasanisamojedien samanismia tutkinut venäläinen Galina Gratక̌jova korostaa myös, että vakiintuneen laulun sanattomalla esitysversiolla on tärkeä semanttinen asema. Hän viittaa erityisesti arktisten kansojen musiikissa keskeisiin henkilökohtaisiin lauluihin. Henkilökohtainen laulu on hänen mukaansa niin tärkeä instituutio pohjolassa, että Brodski ${ }^{5}$ otaksui sanattoman laulun olevan esiverbaalin laulun alkeismuoto - "sen muinaisen ajan lauluja, jolloin puhetta ei vielä ollut". Ilman sanoja esitetyillä sävelmillä voidaan katsoa olevan määrätty semanttinen merkitys, joka osaltaan on syynä siihen, että nganasani- ja nenetsisamojedit ovat sanktioineet erittäin jyrkästi toisen

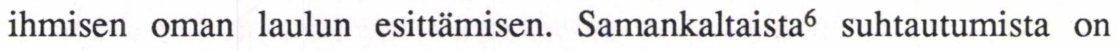
havaittu muillakin Siperian kansoilla. ${ }^{7}$

\footnotetext{
3) Vrt. Gomon 1980, 210.

4) Gomon 1990, 78.

5) Brodski (=Bogdanov) 1976, 254.

6) Mm. Ivanov 1975, 119-126.

7) Gratకjova 1984, 197.
} 


\section{Nenetsien laulujen genret}

Pääasialliset laulugenret ovat: ryhmäidentiteettiä ja yhteisön sosiaalihistoriallista maailmankuvaa heijastavat eeppiset sjudbabc $^{8}$ - ja jàrabclaulukertomukset, yksilö- ja sukuidentiteettiä alleviivaavat sjo- tai xynabc-laulut ja sakraalit samanistiset laulutyypit sàmbadabc ja tàdebco.

Sjudbabcit ja jàrabcit ovat menneen, sukuyhteisöjärjestelmään perustuneen yhteisörakenteen tuotteita ja niiden käyttöyhteys ja olemassaolon tarkoitus ovat hävinneet nenetsien yhteisörakenteen muuttuessa neuvostoajalla tämän vuosisadan alkupuolella. Tämä koskee myös samanistista uskomusjärjestelmää lauluineen. Nykyisin vain vanhimman sukupolven edustajat saattavat osata esittää esimerkiksi omaelämäkerrallista jàrabc-tyyppistä laulukertomusta.

Tänä päivänä elinvoimaiset laulut kuuluvat sjo/xynabc-genreen. Niitä voivat olla mm. metsästys- ja matkalaulut (édaljo"ma xynabc), kehtolaulut (njukubc), häälaulut (tjunja xynabc) henkilökohtaiset laulut (manj jile'man xynabc, humalalaulut (jabe'ma sjo) sekä nykylaulut (janggébc, jedéi sjo), joiden aiheet saattavat olla isänmaallisia, ne saattavat kertoa elämästä ja työstä neuvostoyhteiskunnassa.

\section{Laulujen tonaaliset perusrakenteet}

Sävelmien tonaalisia perus- tai ideaalimuotoja analysoitaessa puoliaskeleettomuutta voidaan pitää kuitenkin ainoastaan karkeana todellisuuden kuvana. Kysymys on myös siitä, että tiettyihin suhteellisiin intervalliyhdistelmiin liittyvä melodian eteneminen ei ole pääasia, vaan kokonaisuudella, laulun rytmis-tonaalisten motiivien toistuvuudella sinänsä, improvisoinnilla sekä (esim. kertovissa lauluissa) tekstin vaikutuksella melodiaan näyttää olevan keskeisempi sija. Kokonaisuuden tärkeä rakenne-elementti on lisäksi se, kuinka laulajat värittävät lauluaan erilaisten äänensävyjen ja mm. mikrointervallien avulla.

8) Nenetsinkielisten sanojen lausuminen: c-kirjaimen äännearvo on (ts); x tarkoittaa hivenen kitkaista h:ta; ng-kirjainyhdistelmällä merkitään nasaalia "ng"-äännettä; "- ja '-merkit tarkoittavat glottaaliklusiilia, joka esiintyy suomen kielessä mm. sanan "kuorma-auto" a-kirjainten välillä; y ääntyy taka-i:nä ja à vastaa suunnilleen pitkää a:ta. Metsänenetsin L-kirjaimella merkitty 1 ääntyy soinnittomana, lukuunottamatta erisnimen Letsama L-kirjainta. 
Ensimmäisiä yksinomaan laulujen sävelrakenteisiin liittyneitä analyyseja oli B. M. Dobrovolskin lyhyehkö kommentaari Z. N. Kuprijanovan toimittamassa "Nenetsien eeppiset laulut" -teoksessa. ${ }^{9}$ Dobrovolski korosti tuolloin, että tallenteiden vähyyden vuoksi laulujen tonaalisista rakenteista on tähän asti voitu tehdä vain ylimalkaisia huomioita. Hän mainitsi pentatonian hallitsevan muutoin intonaatiorakenteiltaan monimuotoisten laulujen sävelrakenteita. ${ }^{10}$ Itse asiassa useimpien laulujen rakenteita ei voida kuvata käsitteellä pentatoninen, pikemminkin voidaan vain viitata kaksi-, kolmi- tai nelisävelikköjen puolisävelaskeleettoman luonteen yleisyyteen.

Dobrovolskin mukaan nenetsien lyyristen ja eeppisten laulujen melodiarakenteissa on huomattavia eroja, mutta niiden intonaatiorakenteet ovat hänen mukaansa selvästi toistensa kaltaisia. Eeppisistä lauluista ei hänen mukaansa ollut olemassa analysointikelpoisia äänitallenteita kuin jàrabcista, mutta silti hänen mukaansa voidaan nykyaikaisia(kin) tallenteita kuunneltaessa erottaa kaksi sävelmärakenteen päätyyppiä. ${ }^{11}$

1) Rytmikaavaan pohjautuva resitointi.

Tonaalisesti tämän tyypin sävelmissä on kyse lähinnä kahden sävelen esimerkiksi perussävelen ja suuren sekunnin tai terssin - vuorottelusta ja tekstin syllabisuudesta (ks. Esim. 5).

2) Laulut, joiden rakenne perustuu yhden, useimmiten kaksisegmenttisen melodiasäkeen kertaamiseen. Näihin lauluihin kuuluvat erityiset alku- ja loppusäkeet. Yksi tavu saattaa sisältää oman melodiasäkeensä. Yleensä tällaisessa tapauksessa melodiasäe vastaa tekstisäettä ja joskus (esim. resitatiivisissa tyypeissä) lauluissa on havaittavissa suuntaus kohti säkeistöllisiä muotoja. (ks. Esim. 9)

Dobrovolski olettaa edelleen, että rakenteellisesti yksinkertaisempi ensimmäinen tyyppi on sjudbabcin ja monimutkaisempi toinen tyyppi járabcin tonaalinen perusta. Hän ei kuitenkaan tee pitkälle meneviä yleisiä johtopäätöksiä analysoimansa aineiston perusteella, koska pitää sitä liian niukkana. Hän esimerkiksi vain olettaa tekstin emotionaalisen sisällön ja melodiasäkeen välillä olevan yhteyttä. ${ }^{12}$

9) Dobrovolski, Kuprijanova 1965.

10) Vrt. Dobrovolski 1965, 757.

11) Ibid., 758.

12) Ibid., 758-759. 
Samana vuonna A. O. Väisänen julkaisi Lehtisalon vuosien 19111914 tallenteista tekemänsä nuotinnoskokoelman, ${ }^{13}$ joka on tähän asti laajin nenetsien laulujen tonaalisia rakenteita käsittelevä analyysi. Väisäsen analyysimetodi, jonka mukaan hän on analysoinut paitsi samojedien myös obinugrilaisten ${ }^{14}$ ja mordvalaisten ${ }^{15}$ lauluja, perustuu sävelmien ryhmittelyyn niiden melodiasäkeiden mukaan. Seuraavassa Väisäsen nuotinnos Lehtisalon vuosien 1911-14 matkoiltaan tallentama kertova laulu. Väisänen on luokitellut sävelmän yksisäkeiseksi. Fonogrammi on huonolaatuinen, sen kiertonopeus huojuu ja se jää jossain kohden pyörimään paikalleen, mutta siltä on kuultavissa koko sävelmän perustana oleva melodiasäekaava, jota laulaja muuntelee.

Esimerkki. 1: Kertova laulu. ${ }^{16}$ Tuntematon esittäjä. Nuotinnos: A. O. Väisänen. ${ }^{17}$
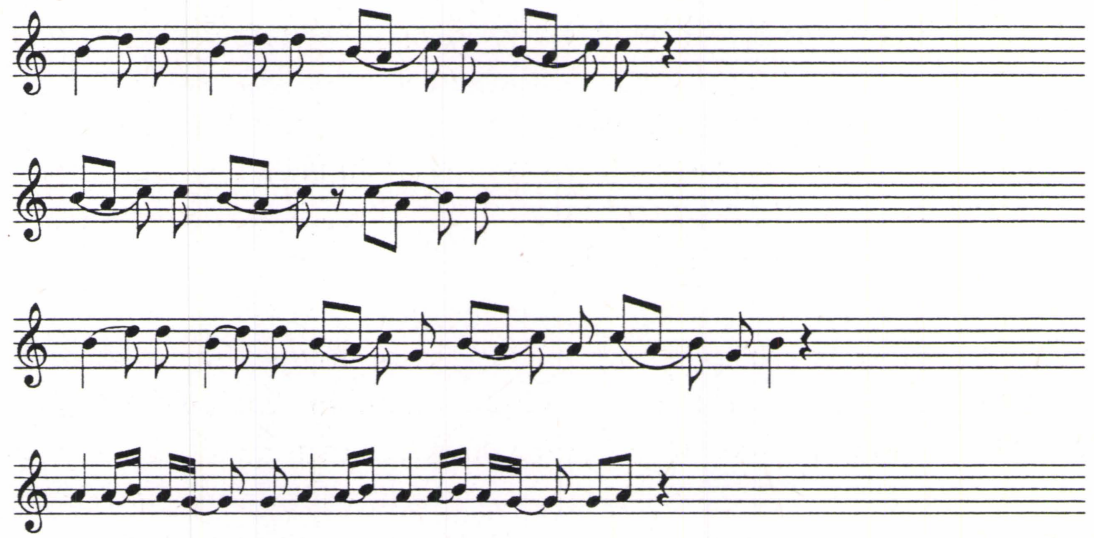

Väisänen on nuotintanut Lehtisalon lieriöiltä yhteensä 56 nenetsiläistä laulua ja ryhmitellyt laulut niiden melodiasäkeiden lukumäärän mukaan. Eniten on kaksisäkeisiä sävelmiä (35), toiseksi eniten yksisäkeisiä (19), kun taas kolmi- ja nelisäkeisiä on kumpaakin yksi kappale.

Hän ei ole jostain syystä katsonut tarpeelliseksi läheskään kaikkien nuotinnosten kohdalla viitata niitä vastaaviin fonogrammeihin, joskin

13) Väisänen 1965.

14) Väisänen 1937, 1939.

15) Väisänen 1948.

16) Fonogrammin lieriökoteloon on kirjoitettu: "kertova laulu hints", mikä viittaa murteellisen kieliasun perusteella siihen, että laulu on tallennettu Uralin länsipuolella. Termi "hints" (xync) viittaa myös lyyriseen xynabciin.

17) Väisänen $1965,4$. 
hän niteen esipuheessa mainitsee Lehtisalon yleensä puutteellisista merkinnöistä vahalieriökoteloissa. Vain yhdeksän nuotinnoksen yhteydessä on viittaus fonogrammiin. Näin laulujen genret jäävät suurimmaksi osaksi arvoitukseksi. Väisänen ei ole myöskään nuotintanut lieriösävelmiä kokonaisuuksina, vaan vain sopivaksi ja edustavimmaksi katsominaan osina.

Lehtisalon omista muistiinpanoista käy ilmi, että lieriöillä olevien laulujen yhteinen lukumäärä on melko tarkasti 50. Näistä neljä laulua on kahdella rikkoutuneella lieriöllä. Väisänen on tosin saattanut nuotintaa viimeksi mainitutkin: lieriöiden rikkoutumisen ajankohta ei ole tiedossa.

Väisäsen sinänsä tarkkoja, eri laulukategorioita edustavia nuotinnoksia on vaikea käyttää apuna tutkittaessa laulujen genrejen välisiä tonaalisia eroja. Asian selvittäminen vaatisi varmuutta Lehtisalon alkuperäistekstien ja niitä vastaavien vahalieriöiden vastaavuudesta.

Vanhat ja elävän käyttöyhteytensä menettävät kertovat laulut antavat rakenteestaan elementtejä perinnöksi nykyaikana elinvoimaisille genreille (sjo/xynabc). Tämä tulee selvästi esille saman esittäjien esittämissä eri genreihin kuuluvissa lauluissa, jotka kuitenkin ovat melodiselta rakenteeltaan samankaltaisia. Gomon antaa esimerkin saman esittäjän laulamasta jàrabcista ja xynabcista. ${ }^{18}$

Esimerkki 2: Jàrabc, esitt. S. T. Apitsyn. Indigan kylä, 1976.

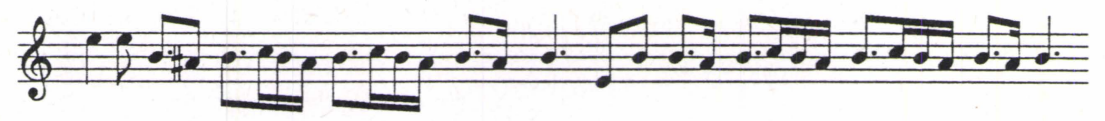

Esimerkki 3: Xynabc, esitt. S. T. Apitsyn. Indigan kylä, 1976.

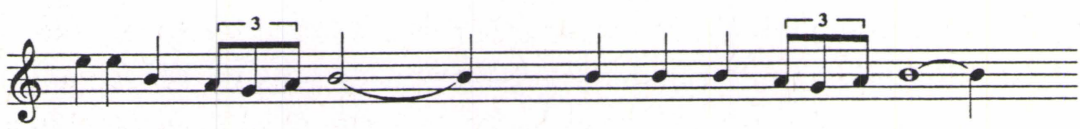

Tällainen genrejenvälinen intonaatioyhteys saman laulajan esityksissä on luonnollista senkin takia, että melodiat ylipäänsä kulkevat ja periytyvät suvun sisällä. Näin ollen se melodian ideaalityyppi, jota esimerkkien 2 ja 3 sävelmien voidaan katsoa edustavan, on ikään kuin "suvun melodia".

Gomon on systematisoinut vuosien 1974-1975 kenttämatkojensa sävelmien rakenteet hieman vastaavalla tavalla kuin Dobrovolski19, "arkaaisempiin" melodisesti kapea-alaisiin resitaatiomuotoisiin ja myö-

18) Gomon 1980, 206.

19) Ibid., 207. 
häisempiin "kehittyneempiin" sävelmiin, joiden tunnuspiirteenä on järjestäytyneempi logiikka ja useat sävelmotiivit (Esim. 4).

Esimerkki 4: Sjo (?), esitt. tuntematon nainen. Jundarkajaha (?), 191113.20
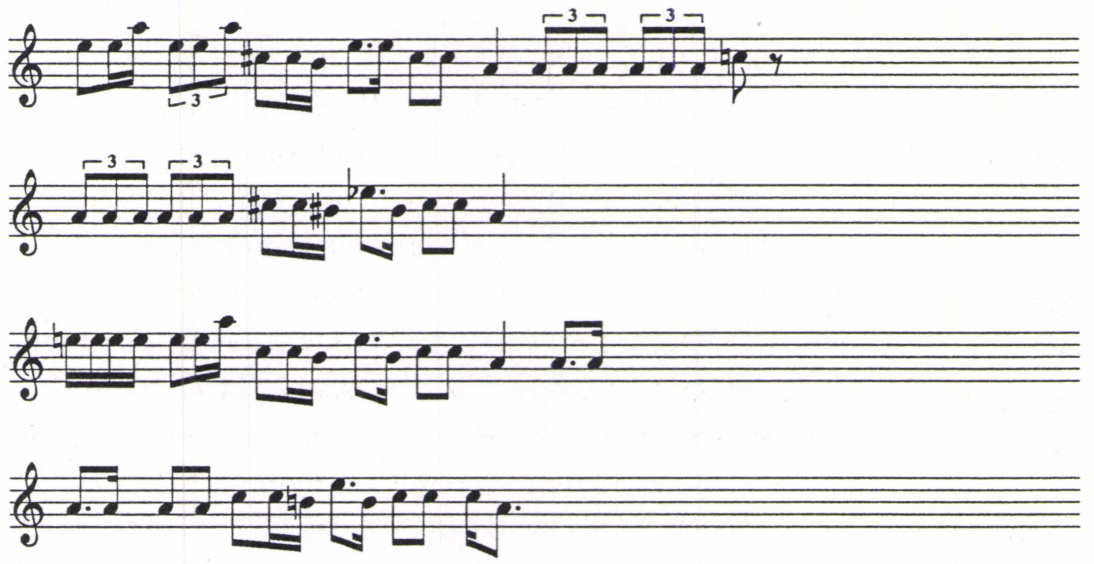

Gomon korostaa tällaisten erojen ilmenevän paitsi genrejen välillä, myös niiden sisällä, mikä havainto puhuu nenetsiläisten laulujen tonaalisen kokonaisrakenteen muuttumisesta. ${ }^{21}$ Tällaisen muutoksen yhtenä luonnollisena syynä voidaan pitää venäläisyyden lisääntyvää vaikutusta lauluissa ja niitä koskevissa arvostuksissa.

Gomon jaottelee tallentamansa laulut niiden tonaalisten ja tekstuaalisten rakenne-erojen perusteella melodiasäkeiltään tasasuhtaisiin ja muuttuviin.

Tasasuhtainen, isometrinen säerakenne on hänen mukaansa tyypillinen esimerkiksi tanssilauluissa. ${ }^{22}$ Tällaisessa laulutyypissä voi vaihdella kaksi melodiasäettä. Hyvin usein sakraalisperäiset laulut kuuluvat rakenteeltaan tähän tyyppiin. Esimerkissä 5 on metsänenetsiläinen samanistinen tapalaulu, joka on sekä tonaaliselta että rytmiseltä rakenteeltaan varsin selkeä.

Rakenteellisesti muuttuvina Gomon pitää erityisesti resitaatiomuotoisina esitettyjä lauluja, joiden melodiasäkeet muuntuvat, eivätkä muodosta kertautuvia ryhmiä. Hänen mielestään tässä suhteessa analogisina voitaisiin pitää esimerkiksi karjalaisia itkuvirsiä. ${ }^{23}$

20) Väisänen 1965, 23; Ph.5.

21) Vrt. ibid., 207.

22) So. yleensä tanssilauluissa; tanssiminen on useimpien lähteiden mukaan ollut tuntematonta nenetseille.

23) Vrt. Gomon 1980, 209. 
Esimerkki 5: Kut\$̌ing djaltoLma. Es. Polina Turutina. Pjakupur 1990.

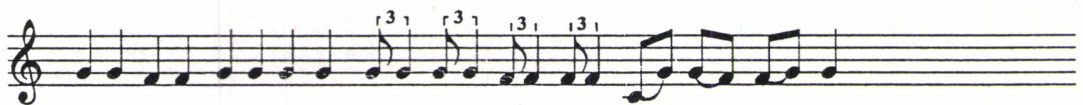

xei xei xei xei xei xei xei xei ku- Ľši ne-mja tă-nj- šta-nga xei xei xei xei,

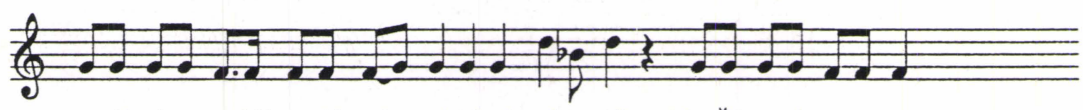

pyng-ki pjan-ta ma-L(a)- xa- t(a) xei xei xei xei, xei xe- xeil ku-tši ne-mja ma-ny-ngan

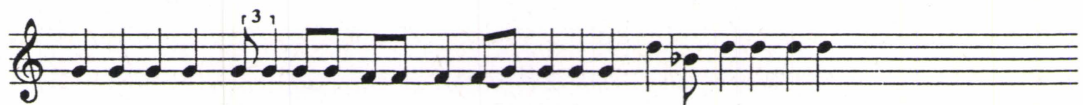

xei xei xei xei nga-my a- pym ma-ny- ngan xei xei xei xei, xei xe- xei xei xei xei!

Usein deskriptiivisillä ja puoliksi improvisoiduilla henkilökohtaisilla lauluilla on tällainen muuttuva melodinen rakenne, kuten seuraavassa metsänenetsiläisen Letsama Wé"lan laulussa (Esim. 6).

Esimerkki 6: Wé"la Letšamang sho. Es. Polina Turutina Pjakupur, 1990.
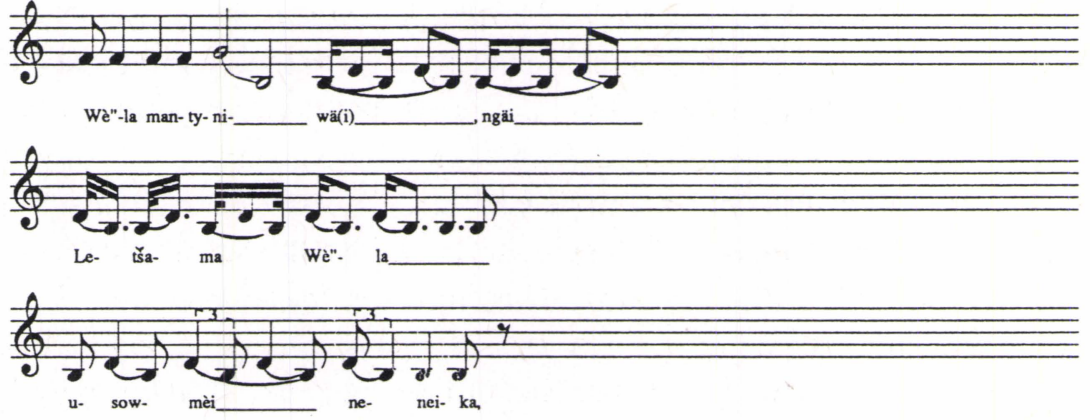

Kaksisäkeiset melodiat ovat kuitenkin enemmistönä esimerkiksi Herzeninstituutin opiskelijoiden laulamissa lauluissa. Lehtisalon vuonna 1957 instituutissa tallentama laulu koostuu kolmesta säkeestä, joista kaksi ensimmäistä ovat samanlaisia. Säkeiden järjestyminen AAB-muotoon on tosin vain oletus, koska laulaja keskeyttää laulunsa kahdesti - ilmeisesti muistellakseen jatkoa. Ei ole myöskään varmaa, lopettaako laulaja koko tekstin päätökseen, vai laulaako hän vain muistamansa osan lopettaen sen sattumanvaraiseen kohtaan. 
Esimerkki 7: Sjo, tuntematon esittäjä, nainen. Leningrad, 1957.

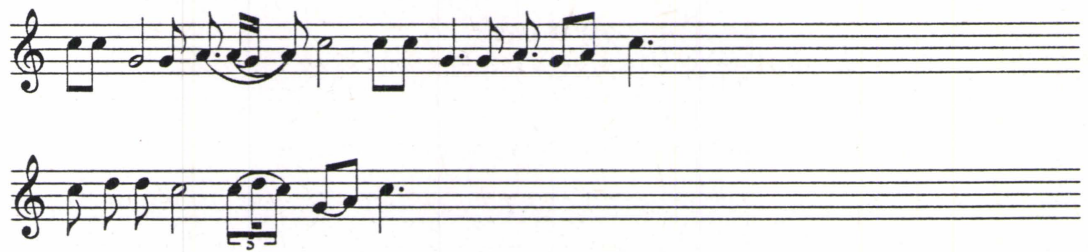

Hantilaista häälaulua analysoinut (hantilainen) L.Taragupta kiinnittää huomiota laulun eri rakenne-elementtien limittäisyyteen, jonka hän tulkitsee laulua eteenpäin vieväksi dynaamiseksi ominaisuudeksi. Laulun melodia- ja tekstisäkeiden rajat eivät yhtene ja näin syntyy Taraguptan mukaan tauottomuuden, loppumattomuuden tunnelma. Kun melodiasäe loppuu, tekstisäe jatkuu yhä ja niin edelleen. ${ }^{24}$ Nenetsiläisissä lauluissa voi olla kysymys samankaltaisesta ilmiöstä varsinkin, kun otetaan huomioon, etteivät laulajien hengitysjaksot useinkaan häiritse tai rajoita laulun tonaalista ja tekstuaalista segmentoitumista.

Gomon puhuu myös sävelten eräänlaisesta tonaalisesta ideaalirakenteesta, jonka voidaan ajatella muodostavan sävelmän tonaalisen kokonaisuuden vasta yhdessä esiintyjäkohtaisen äänentuottamisen kokonaistavan kanssa. Laulusta tehty nuotinnos ei esimerkiksi anna käsitystä äänen sävyominaisuuksista, joihin laulaja voi vaikuttaa esimerkiksi vaihtelemalla äänen resonointipaikkaa (päätä, nenäonteloa, tms.).

Hänen mukaansa myös erityisten "piiloäänien" voidaan ajatella edustavan lauluissa ilmenevää ajateltua ylärakennetta. Tämän ylärakenteen luonne on Gomonin havaintojen mukaan vastaavanlainen kuin jakuuttilaisten laulujen nk. "laajenevassa asteikossa". ${ }^{25}$ Jakuuttien lauluja tutkineen Eduard Aleksejevin (itsekin jakuutti) mukaan niille on tyypillistä erityinen laajeneva sävelikkö. Sen rungon muodostaa 1-3 akselisäveltä, joiden ylä- ja alapuolelle syntyy ikään kuin laulun tonaalinen avaruus. Tällä tilalla on Aleksejevin mukaan taipumus laajeta molempiin suuntiin esityksen kuluessa. Akselisäveltenkin absoluuttinen sävelkorkeus nousee, koska kysymys on säestyksettömästä yksinlaulusta, mutta ei niiden hahmottamisen kannalta merkittävästi - toisin sanoen niiden keskinäiset suhteet pysyvät vakioina. ${ }^{26}$

Tällaisen tonaalisen laajenemisen lisäksi jakuuttilaisten laulajien esitystyyliin kuuluu sävelmän nopeuden kasvu sekä laulajan äänen voimakkuuden lisääntyminen. Aleksejevin mielestä kysymys on laulun - ja

24) Taragupta 1986, 306.

25) Gomon 1980, 210.

26) Aleksejev 1976, 49. 
sen tekstin aiheuttamasta tunnelatauksesta, joka kiihdyttää laulajaa siinä määrin, että tuloksena on laulun tonaalisen rakenteen asteittainen muuttuminen esityksen kuluessa. ${ }^{27}$

Aleksejev korostaa, että kysymys on eri asiasta kuin laulun tonaalisen kokonaisrakenteen asteittaisesta noususta, mikä on täysin luonnollinen ilmiö säestyksettömässä laulussa. Hän kuitenkin korostaa vielä laajenevan sävelikön esiintyvän todennäköisesti muidenkin kansojen lauluissa ja erityisesti sellaisissa, joiden esittämisen konteksteille on tyypillistä "kohottunut emotionaalinen mielentila". ${ }^{28}$

Gomon antaa seuraavan nuotinnoksen esimerkkinä havaitsemastaan sävelikön laajentumasta nenetsiläisessä xynabcissa. Ympyröidyt nuotit edustavat sävelmän laajenevaa tonaalista ylä- ja neliöidyt alarajaa. ${ }^{29}$

Esimerkki 8: Xynabc, esitt. J.A.Belugina. Indigan kylä, 1976.
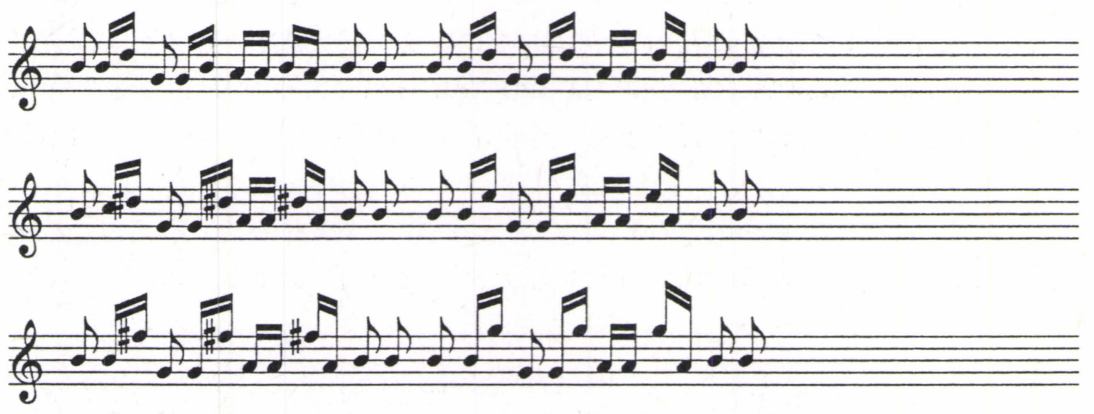

Samanaikaisesti melodiaäänen kanssa soivilla yläsävelsarjaääneksillä on myös merkitystä nenetsiläisessä laulussa. Ääneslaulusta on eniten esimerkkejä Sajanin tuvien ja länsimongolien ns. kaksiäänisessä kurkkulaulussa. Tuvien ja mongolien tapauksessa itse asiassa melodinen päätehtävä on nimen omaan resonanssisävelillä ja pohjaääni toimii lähinnä bordunana. Vastaavan kaltaisella, samanaikaisesti kaksi ääntä tuottavalla äänenmuodostuksella laulavat myös muut Etelä-Siperian, Sajanin ja Altain turkkilaiskansojen kertovien laulujen esittäjät. Näillä kansoilla tie-detään äänesten olevan melodisesti keskeisiä. Muualla kaksiäänisyyden olemassaolosta ylipäänsä on myös esimerkkejä, mutta sillä ei - todennäköisesti - ole niin selkeätä ja tiedostettua tehtävää äänenmuodostuksessa kuin em. kansojen musiikissa. Jakuuttien eeppisten laulajien tiedetään tosin myös käyttävän erityistä kylyhax-tekniikkaa, jonka avulla

27) Vrt.ibid., 56.

28) Ibid., 57.

29) Gomon 1980, 210-211. 
voidaan lisätä pohjaäänen koristeeksi eri äänentuottotekniikalla tuotettu lisä-ääni. ${ }^{30}$

Ilpo Saastamoinen on havainnut äänesten soivan myös mm. tక̌utకien lauluissa, mutta esimerkkejä kuunnellessa voi selvästi havaita eron tšuktšilaisen ja tuvalaisen ääneslaulun välillä. On todennäköisempää, että yläsävelten tuottamisella ei ole arktisten kansojen lauluissa samalla tavoin itsenäistä tonaalista tehtävää kuin tuvalaisilla, vaan pikemminkin kyse näyttää olevan vain tietyn kaltaisen äänentuottotavan tonaalisena ilmenevästä akustisesta ominaisuudesta. Arktisten kansojen latentti kaksiäänisyys ilmenee parhaiten akustisesti edullisissa olosuhteissa ja esimerkiksi Saastamoisen nuotintamat tšuktšien laulut ${ }^{31}$ ovat peräisin sisätilassa nauhoitetulta äänilevyltä ja tilan akustinen kaiku auttaa tuomaan laulun ääneksiä kuuluviin. Vastaavasta piilevästä ääneslaulusta nenetsien lauluissa on esimerkkinä Jelena Susoin laulama sjo "Hopeanhohtoiset porot". Myös tämä tallenne on äänilevyltä ja se on tehty huoneakustiikassa. Kun laulaja laulaa esisäkeen rungon muodostavaa säveltä (b1) pitkänä, hänen äänensä muodostaa kaiunomaisen yläsävelen (f3). Vastaava ilmiö tapahtuu jälkisäkeessä, jonka runkosävel (c2) saa seurakseen yläsävelen (g3):

Esimerkki 9: Sjo "Hopeanhohtoiset porot", esitt. Jelena Susoi, Salehard. (Melodija S30-19759 007)

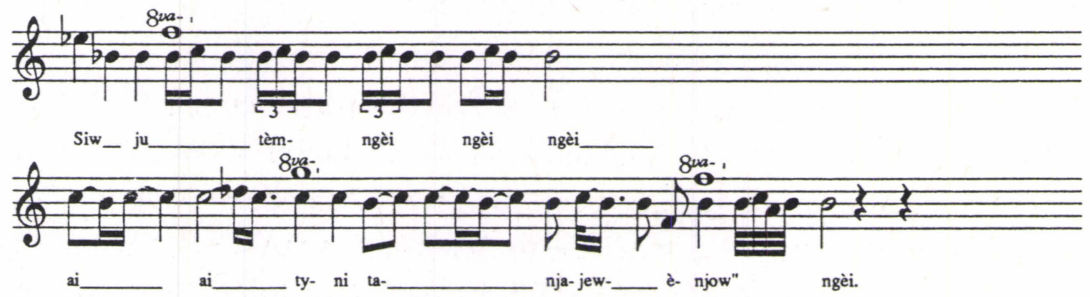

Susoin esityksestä voi lisäksi huomata, että ylä-äänten esiintyminen korreloi tiettyjen vokaalien, esimerkiksi "o":n ("ju") kanssa. Tämän vuoksi voidaan tietenkin esittää oletus myös äänesten tietoisesta tuottotavasta ja tonaalisesta tehtävästä, kun muistamme esimerkiksi tuvien hallitsevan äänesten säveltasoa nimen omaan eri vokaaleja lausumalla.

Mielenkiintoinen kysymys on lopulta myös rytmisten rakenteiden luonne nenetsien lauluissa. Arktisten kansojen lauluissa saattaa olla hyvin monimutkaisia, mutta säännöllisiä rytmisiä rakenteita, joiden lain-

30) Aleksejev 1976, 8.

31) Saastamoinen 1985, n:ot 57 ja 60. 
alaisuudet eivät välttämättä paljastu eurooppalaiselle havaitsijalle kuin ehkä perusteellisen analyysin jälkeen. Tällaisia rakenteita esiintyy paljon koko Euraasian ja Siperian alueella, niin saamelaisissa joiuissa kuin eskimoiden lauluissakin.

Arktisen laulun analyysi on ainakin Siperian osalta vasta alussa. Vihjeitä musiikkianalyysin mahdollisuuksista antaa mm. Pantaleoni, joka on havainnut dakota-intiaanien laulujen rytmisen pulsaation kulkevan ainakin kolme kertaa nopeammin kuin länsimaisessa musiikissa. Ilmiö paljastuukin länsimaiselle analysoijalle vasta nauhaa hitaammalla nopeudella analysoitaessa. Lisäksi laulujen tarkka rytminen analyysi osoittaa, että niissä lauluissa, joita säestetään rummun lyönneillä vallitsee täydellinen laulun ja rytmin koordinaatio, mitä ei ennen uskottu olevan lainkaan Pohjois-Amerikan intiaanien musiikissa. Pantaleonin mukaan viitteitä pulssin jaksottumisesta antaa laulajan vibrato. ${ }^{32}$ Pantaleonin havainto on varsin mielenkiintoinen, mikäli ryhdytään jäljittämään samankaltaisia piirteitä Siperian arktisesta musiikista, joka kuuluu pitkällä historiallisella perspektiivillä suureen yhtenäiseen sirkumpolaaris-subarktisperäiseen kulttuurialueeseen Saamenmaasta Tulimaahan. Rytmiikan hienojakoisuus ja sen selvittäminen saattaa avata täysin uusia näköaloja käsitteille "resitaatio" ja "vapaarytminen".

Seuraavassa metsänenetsiläisessä lastenlaulussa vuorottelevat rytmiset yksiköt, joita voidaan havainnollisesti kuvata kahden ja kolmen yksikön hronos protoksista koostuviksi. Rytmi vakiintuu ensimmäisen melodiasäkeen jälkeen ja sitä rikkovat jatkossa vain hengitystauot.

Esimerkki 10. KoLysa. Esitt. Polina Turutina. Pjakupur 1990.
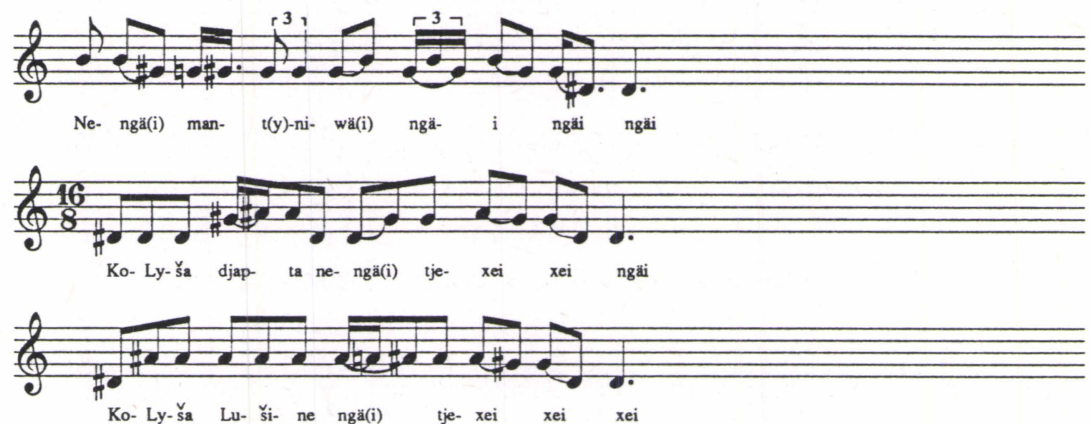

32) Pantaleoni 1987, 35; 39. 
Uudemmat nenetsiläiset laulut edustavat - kuten voi arvata - siirtymävaihetta kohti eurooppalaisessa mielessä säännönmukaisempia tonaalisia ja rytmisiä muotoja. Näissä lauluissa voidaan havaita venäläinen vaikutus suhteellisen selkeästi, vaikka useimmiten perinteisen nenetsiläisen laulun tonaaliset rakenteet ovat silti helposti havaittavissa.

Lehtisalo vieraili vielä vuonna 1957 Leningradin Herzen-instituutissa ja tallensi siellä muutamia lauluja. Ne edustavat - yhtä loitsuresitaatiota lukuun ottamatta - jo nykynenetsiläistä, rytmisesti ja tonaalisesti selkeämmin hahmotettavaa laulutyyppiä. Esimerkissä 11 on pohjoisille kansoille luonteenomainen anhemitoninen sävelikkö, jossa on kaksi kokosävelaskelta ja yksi pieni terssi (h-c\#-d\#-g\#). Laulajan hengitysrytmi ja tekstisäkeet aiheuttavat luonnolliset muutoksensa melodiseen rakenteeseen. Esimerkissä 12 on myös samankaltainen sävelikkö, mutta sen runkona on viisi säveltä (c-d-e-g-a). Esimerkki 13 on poikkeus anhemitonisuuden suhteen (d-e-f-a). Kaikki nämä sävelmät ovat tonaaliselta ja rytmiseltä rakenteeltaan suhteellisen vakaita ja tässä mielessä ne edustavat toisenlaista sävelmänmuodostuksen maailmaa, kuin aiemmat esimerkit.

Esimerkki 11: Sjo, tuntematon esittäjä, nainen. Leningrad, 1957.
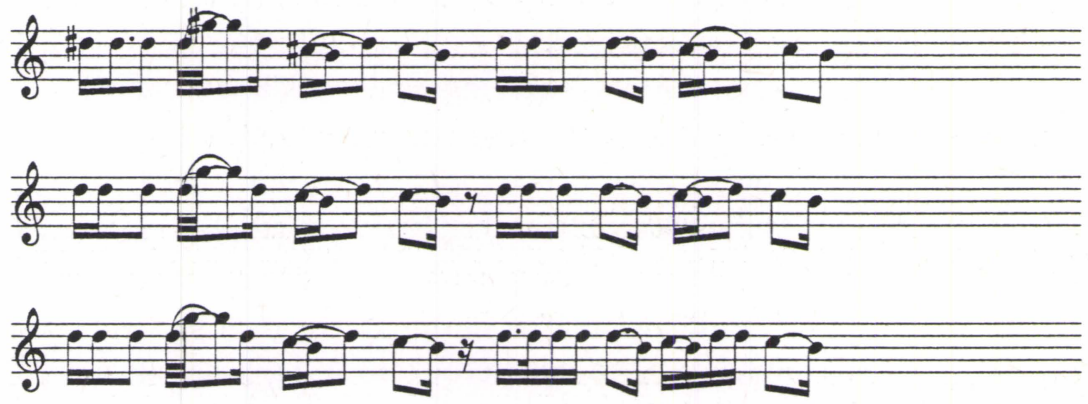

Esimerkki 12: Sjo, tuntematon esittäjä, nainen. Leningrad, 1957.
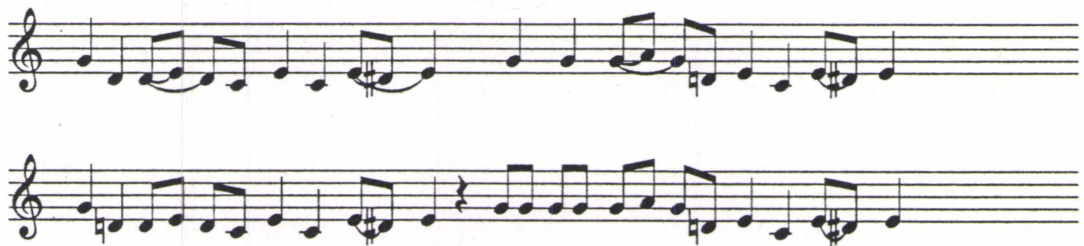
Esimerkki 13: Sjo, tuntematon esittäjä, nainen. Leningrad, 1957.

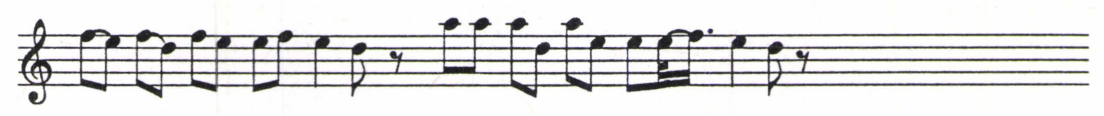

Janhusen Herzen-instituutissa vuosina 1979 ja 1980 tallentamat laulut edustavat jo yksinomaan tällaisia "nykynenetsiläisiä" sävelmiä, joille on tyypillistä sävelten selkeä rytminen jäsentyminen, mikä siis tarkoittaa myös muutosta laulajien esityskäytännöissä. On muistettava, että esimerkiksi Leningradin Herzen-instituutin Ääripohjolan kansojen tiedekunnassa on systemaattisesti opetettu tanssia ja laulua opiskelijoille jo 1930-luvulta lähtien. Venäläiset musiikinopettajat ja koreografit ovat antaneet laitoksen opiskelijoille perustiedot mm. äänenmuodostuksessa ja tanssiliikkeissä. Pyrkimyksenä on ollut luoda synteesi arktisten musiikkikulttuureiden laulujen ja tanssien pohjalta laadittujen sävellysten esittämiseksi eurooppalaisin keinoin. ${ }^{33}$ Herzen-instituutin opiskelijoilta tallennetut sävelmät eivät siis varsinaisesti edusta arktista laulua - ja tässä tapauksessa nenetsiläistä perinteistä laulua - vaan nykynenetsiläistä sävellettyä musiikkia. Herzen-instituutissa tehdyt tallenteet eivät toisin sanoen ole yksin millään tavoin edustavia nenetsiläisen laulun ja sen tyylikeinojen kokonaisuuden tutkimisen kannalta. Vanhat muodot ovat kuitenkin vielä olemassa. Tästä ovat osoituksena mm. vuoden 1987 tallenteet Obinlahdelta, jotka vastaavat tyylillisesti Lehtisalon vuosien 1911-1914 tutkimusmatkan tallenteita.

Janhusen tallenteista ja 1980-luvun nykynenetsiläisestä laulusta olkoon esimerkkinä tshastushkamainen, selkeän harmoninen sjo (Esim. 14.). Laulut 14-16 ovat nenetsiläisten säveltäjä Semjon Njàruin ja runoilija Leonid Laptsuin käsialaa.

Nykyisten laulujen "kiinteytyvien" rakenteiden ominaisuuksiin kuuluu myös se, että eri esittäjät laulavat niistä miltei identtisiä versioita. Toisin sanoen tonaalinen mikromuuntelu katoaa ja sävelmistä tulee identtistä, kansallista, esineellistynyttä omaisuutta.

Seuraavista kahdesta (Esim. 15, 16) saman sjo-laulun versioista ensimmäinen on Janhusen vuonna 1979 tallentama ja toinen on oma tallenteeni vuodelta 1988. Jäänteenä perinteisistä nenetsiläisistä tonaalisista rakenteista ovat suuret (kvintin tai kvartin ) intervallihypyt.

33) Vrt. esim. Kolesin 1986, 259-260. 
Esimerkki. 14: Sjo, esitt. Nadežda Njàrui. Leningrad, 1979.
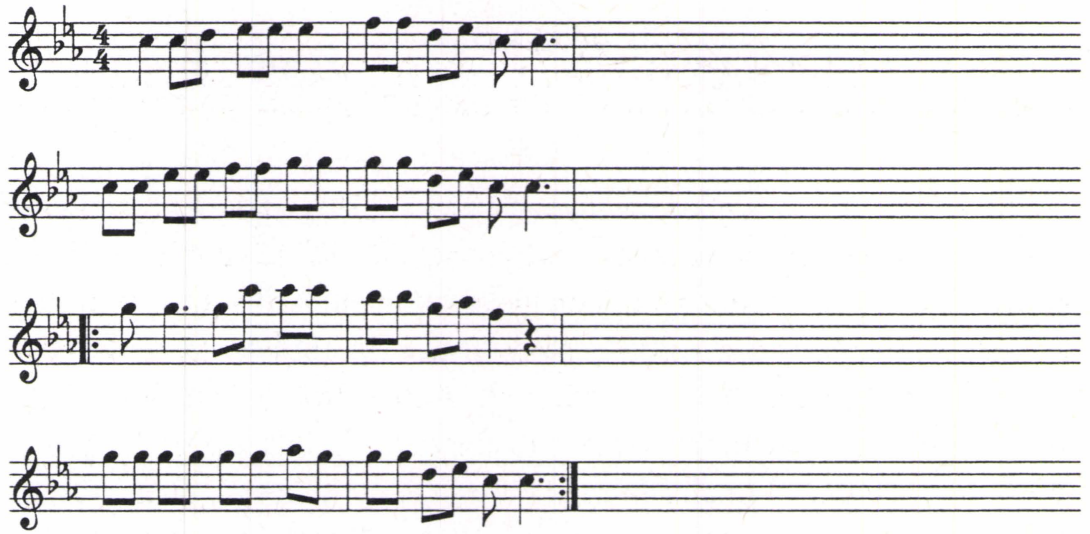

Esimerkki 15: Sjo ("Kalastajien laulu"), tuntematon esittäjä, nainen. Leningrad 1979.
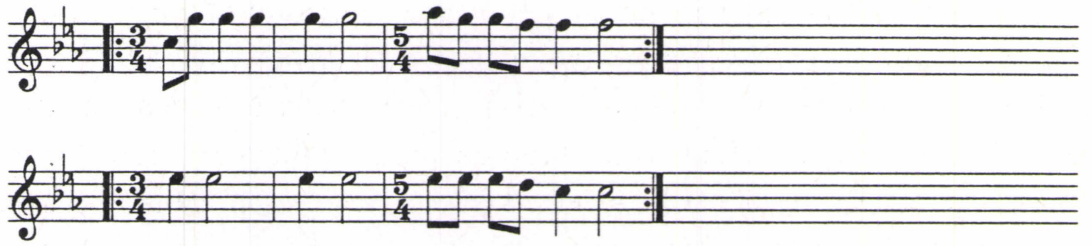

Esimerkki 16: Sjo ("Kalastajien laulu"), esitt. Svetlana Salenter. Leningrad 1988.
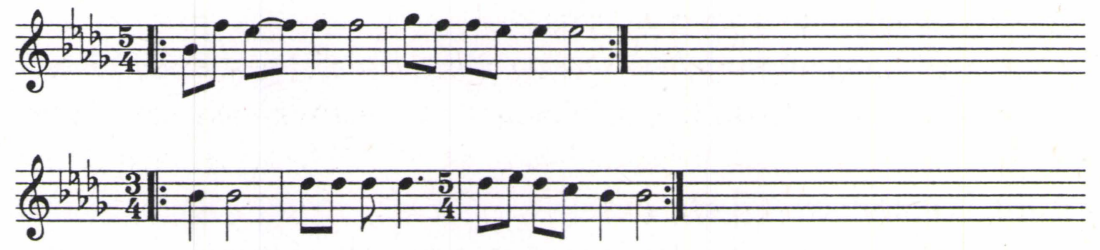

Neuvostotyyliin sävellettyjen nykylaulujen puhtaana esimerkkinä on instituutin opiskelijoiden perinnetanssiryhmän nuorilta jäseniltä tallentamani kaksiääninen laulu, johon kuului pianosäestys. Myös tämän laulun viimeinen säkeistö laulettiin venäjäksi. Huom. säkeiden loppujen oktaavistemmat (Esim. 17).

On kuitenkin todettava, että pohjoisessa, laulujen luontaisilla syntysijoilla, esimerkiksi tundran poronhoitajien keskuudessa on vielä alueita, jotka eivät ole vieläkään joutuneet alueellisten keskusten tavoin elimelliseen, asteittain kulttuuriseen assimilaatioon johtavaan vuorovaikutukseen valtakulttuurin kanssa. Näillä alueilla voitaisiin romantisoidusti vielä sanoa "perinteisen nenetsiläisen laulun" säilyneen miltei 
muuttumattomana. Mutta ajan kuluessa ja akkulturaatioprosessin edetessä myös ihmisten arvostukset muuttuvat. Muun muassa vuoden 1988 Leningradin matkani tuliaisina korviini jäi soimaan erään nuoren, kaukaa Taimyrilta kotoisin olevan nenetsiopiskelijan hämmästys: "Mutta miksi ihmeessä te oikein tutkitte nenetsien lauluja? Eihän niissä ole mitään tutkimista!"

Esimerkki 17: Sjo, tuntemattomat esittäjät, tyttöjä. Leningrad 1988. Säveltäjä ei tiedossa.
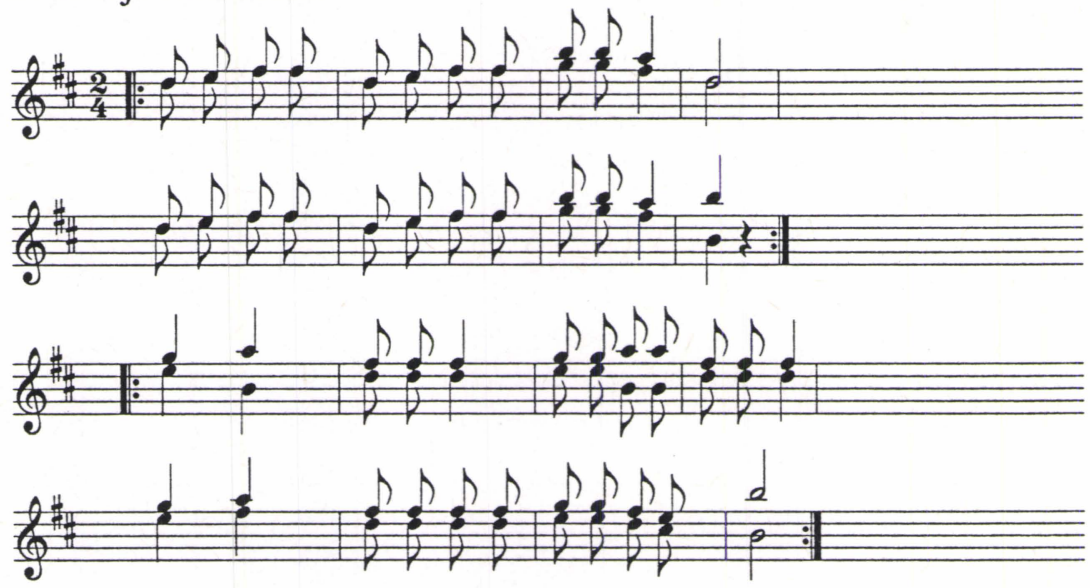

Asetettakoon lopulta vielä kuriositeetin vuoksi rinnakkain vuonna 1987 Obinlahdelta tallennettu nenetsiläinen laulu Kai Donnerin vuonna 1912 Abalakovassa tallentaman kamassisamojedilaisen laulun kanssa. Näiden kahden laulun tonaalinen kieli antaa kohtalaisen hyvän yleiskuvan Obilla ja Jeniseillä asuneiden uralilaisten alkuperäiskansojen musiikista. Luonteenomaisia melodisen rakenteen piirteitä ovat anhemitoninen kolmisävelikkö sävelrunkona sekä kolmijakoinen (trokee- tai vastatrokeemuotoinen) rytmiikka.

Esimerkki 18: Sjo, tuntematon esittäjä, nainen. Obinlahden etelärannikko 1987. Tallenne: TaYO/KPL:n kokoelmat 9815.
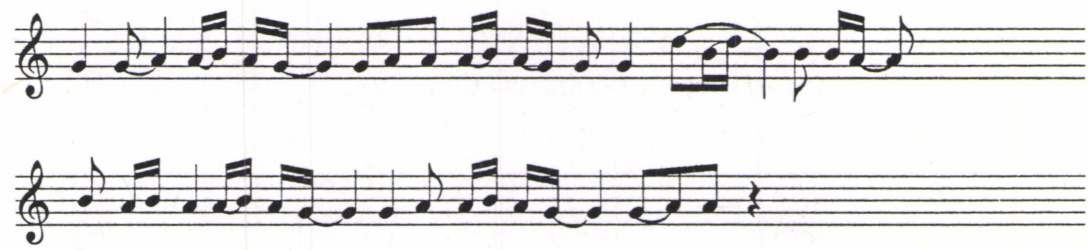
Esimerkki 19: Kamassilainen laulu, esitt. Avdakeja Andžigatova. Abalakova 1912.34
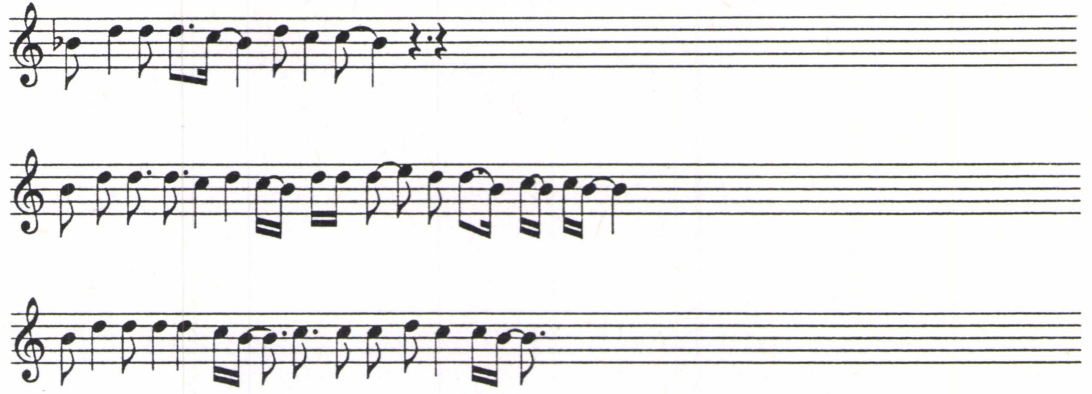

Kahden viimeisen esimerkin sävelmillä on ikäeroa 75 vuotta, vaikka ne voisivat olla samaan aikaan samasta paikasta tallennettuja. Tänä aikana kamassien suku on ehtinyt hiipua olemattomuuteen ja nenetsit ovat matkalla kohti kulttuuriassimilaatiota ja paikoin myös uhkaavana häämöttävää ekokatastrofia, ellei kansallisen vähemmistöpolitiikan suunta muutu lähitulevaisuudessa. Lauluista voi kuitenkin jäljittää reitin kaukaiseen uralilaiseen menneisyyteen, kenties jopa ajalle ennen samojediheimojen erkaantumista. Se reitti on vielä suureksi osaksi tutkimatta.

\section{Lähteet}

Aleksejev E. A.

1976 Problemy formirovanija lada. (Na materiale jakutskoj narodnoj pesni). Moskva.

Brodski I. A.

1976 K izutŠeniju muzyki narodov Severa SSSR. Sbornik trudov Gosudarstvennogo muzykalno - pedagogitYeskogo instituta im. Gnesinyh XXIX. Moskva.

Dobrovolski B. M.

1965 O napevah epitక̌eskih pesen. Nenetskije epitšeskije pesni. Moskva.

Gomon A. G.

1980 O nekotoryh osobennostjah traditsionnyh nenetskih improvizatsii. Finno-ugorskij muzykalnyj folklor i vzaimosvjazi s sosednimi kulturami. Tallinn.

34) Vrt. Väisänen 1965, 48. 
1990 Expanded Melodic Scale in the Oral Tradition of the Nenets Folksong. Ural-Altaic Yearbook 62. Bloomington.

Grat\$jova G. N

1984 Shaman Songs and Worldview. Shamanism in Eurasia

Ivanov S. V.

(Part I). Göttingen.

1975 Drevnyje predstavlenija nekotoryh narodov Sibiri o slove, mysli, obraze. Strany i narody Vostoka XVII. Moskva.

Kolesin A. N.

1986 Razvitije horeografitక̌skih traditsii narodnostej Severa.

(O tvortšestve T.F. Petrovoj-Bytovoj). Kultura

narodnostej Severa: traditsii i sovremennost. Novosibirsk.

Niemi Jarkko

1989 Nenetsien musiikkikulttuuri: laulut ja soittimet. Pro gradu

Pantaleoni Hewitt -tutkielma. Tampereen yliopisto. (Painamaton).

1987 One of Densmore's Dakota Rhythms Reconsidered.

Ethnomusicology 1/1987.

Saastamoinen Ilpo

1985 Kansat soittavat. Helsinki.

Taragupta L.

1986 "Ai luh posl éwi"-hantyjskaja narodnaja pesnja. Muzyka v svadebnom obrjade finno-ugrov i sosednih narodov.

Tallinn.

Väisänen Armas Otto

1937 Wogulische und Ostjakische Melodien. SUST 73.

Helsinki.

1939 Untersuchungen über die Ob-ugrischen Melodien. SUST 80. Helsinki.

1948 Mordwinische Melodien. SUST 92. Helsinki.

1965 Samojedische Melodien. SUST 136. Helsinki.

\section{Tallenteet:}

1. Toivo Lehtisalo, SKSÄ D-D-F 23 A 516/18, Ph.12.

2.,3. ja 8. Alla Gomon.

4. Toivo Lehtisalo, SKSÄ D-D-F 22 A 516/14, Ph.5.

5.,6. Nuni Wé"la.

7.,11.-13. Toivo Lehtisalo.

9. Melodija S30-19759 007, B10. 
10. Nuni Wé"la.

14.,15. Juha Janhunen.

16. Jarkko Niemi, TaYO/KPL Y 9830.

17. Jarkko Niemi, TaYO/KPL Y 9823.

18. Jarkko Niemi, TaYO/KPL Y 9818.

19. Kai Donner, SKNA, Ph.19. 